\title{
DETERMINAN RETURN SAHAM: JAKARTA ISLAMIC INDEX VS LQ 45
}

\author{
Eka Ajeng Dian Anggraini \\ Universitas Islam Negeri Maulana Malik Ibrahim Malang \\ ajengeka60@yahoo.com \\ Ahmad Sidi Pratomo \\ Universitas Islam Negeri Maulana Malik Ibrahim Malang \\ ahmad@pbs.uin-malang.ac.id
}

\section{Abstract}

The aims of this research are to know the influence of modal structure, systematical risk, and liquidity to the contribution return that is done by differentiating two indexes; Jakarta Islamic Index (JII) and Liquid 45 (LQ45). This research is a qualitative research which takes the samples in the companies that is listed in JII and LQ45 period 2014-2016. The total samples are 33 companies by using purposive sampling method. In doing the analysis, this research is using a doubled regression method and balance test by using SPSS 21 program. The result of this research shows that the variable of systematic risk of JII and LQ45 indexes have a significant influence to the contribution return. However, the variable of the financial capital and liquidity of JII and LQ45 indexes does not have a significant influence to the contribution return. In the result of balance test, there is a significant difference in the variable of modal structure in JII and LQ45. Here, the different result will show that there are no significant differences between the variables of systematical risk, liquidity, and contribution return in JII and LQ45.

Keywords: Modal Structure, Systematical Risk, Liquidity, Contribution Return

\section{Abstrak}

Tujuan dari penelitian ini adalah untuk mengetahui pengaruh struktur modal, resiko sistemik dan likuiditas terhadap kontribusi pengembalian dengan membandingkan dua indeks: Jakarta Islamic Index dan LQ 45 Bursa Efek Indonesia. Penelitian ini menggunakan metode kuantitatif dan teknik purposive sampling untuk mendapatkan sampelnya yakni 33 perusahaan. Regresi linier berganda dengan SPSS 21 digunakan sebagai alat analisis data dalam penelitian ini. Hasil penelitian ini menunjukkan bahwa resiko sistemik JII dan LQ 45 memiliki pengaruh yang signifikan terhadap kontribusi pengembalian. Namun, modal keuangan dan 
likuiditas JII dan LQ 45 tidak berpengaruh signifikan terhadap kontribusi pengembalian. Hasil dari balance test tidak ada perbedaan yang signifikan pada struktur modal yang ada di JII dan LQ 45. Oleh karena itu, perbedaan hasil dalam penelitian ini akan menunjukkan bahwa tidak ada perbedaan yang signifikan antara variabel risiko sistemik, likuiditas dan kontribusi pengembalian yang ada pada JII dan LQ 45.

Kata kunci: Struktur modal; Risiko Sistemik, Likuiditas, Kontribusi Pengembalian

\section{PENDAHULUAN}

Sekarang ini dunia bisnis banyak didukung oleh berbagai macam alternatif yang ditawarkan dalam berinvestasi seperti sekuritas maupun investasi asset riil. Salah satu alternatif investasi yang sedang mengalami peningkatan tahun ini adalah pasar modal. Pasar modal merupakan sarana alternatif perusahaan untuk mempermudah jalannya usaha kolaboratif tertentu dalam mengembangkan sebuah perusahaan. Hal tersebut dinilai sangat membantu ketika perusahaan sedang membutuhakan dana maksimal dalam periode yang cukup lama.

Investor sebagai pihak yang memiliki dana berlebih dapat menginvestasikan dananya di pasar modal pada berbagai pilihan investasi untuk meningkatkan keuntungan. Kegiatan investasi tentunya diharapkan dapat menghasilkan pengembalian saham atau biasa disebut dengan return saham. Dalam memilih investasi dengan return yang tinggi, investor memerlukan berbagai informasi sebagai landasan untuk menentukan keputusan yang akan diambil. Informasi yang dapat digunakan untuk menentukan keputusan yang diambil adalah laporan keuangan perusahaan. Kinerja perusahaan dapat dicerminkan melalui laporan keuangan perusahaan seperti, kinerja keuangan dan yang bukan keuangan. Struktur modal merupakan salah satu alat untuk mengkur kinerja perusahaan. Menurut Irham (2012) struktur modal adalah deskripsi dari bentuk proporsi financial perusahaan yaitu antara modal yang bersumber dari utang jangka panjang (long term liabilities) dan modal sendiri (shareholders' equity).

Namun penggunaan modal yang berasal dari utang bisa menaikkan risiko seperti bunga. Pada dasarnya setiap investasi pasti 
memiliki risiko masing-masing. Risiko akan selalu berbanding lurus terhadap return saham yang artinya apabila investor menginginkan return saham yang besar, maka risiko yang diterima juga besar, hal ini dikarenakan risiko merupakan faktor yang menentukan tingkat pengembalian.

Selain itu, Investor dapat menilai kinerja perusahaan dengan melihat tingkat likuiditas perusahaan tersebut. Menurut Fahmi (2012), likuiditas yakni proporsi kemampuan perusahaan dalam memenuhi kewajiban utang jangka pendenknya dengan tepat waktu. Semakin bagus kinerja perusahaan maka artinya semakin tinggi nilai likuiditas perusahaan tersebut. Jadi investor semakin percaya kepada perusahaan dan aka berpengaruh pada peningkatan harga saham sehingga berimbas ke naiknya return saham, dan investor dapat menerima return yang besar.

Indeks yang paling dikenal oleh banyak investor adalah Indeks Likuid 45 (LQ45) dan Jakarta Islamic Indeks (JII), kedua indeks saham tersebut memiliki daftar yang aktif dan likuid dibandingkan daftar saham pada indeks lainnya. Indeks LQ45 dan JII adalah indeks yang diamati kinerjanya oleh investor karena dipercaya dapat memberikan return yang tinggi dan dianggap dapat memberikan return saham yang cukup tinggi dikarenakan saham-saham yang berada di Indeks tersebut merupakan saham-saham yang unggul.

Sesuai dengan uraian penjelasan di atas, maka dapat diambil judul "Pengaruh Struktur Modal, Risiko Sistematis dan Likuiditas terhadap Return Saham (Studi Komparasi Perusahaan yang Listing di JII dan LQ45 2014-2016)".

\section{TINJAUAN PUSTAKA}

\section{Struktur Modal (X1)}

Sutrisno (2003: 289) menyatakan bahwa "struktur modal merupakan imbangan antara modal asing atau hutang dengan modal sendiri (debt to equity ratio)"

Debt Equity Ratio (DER) digunakan untuk mengukur proporsi antara kewajiban yang dimiliki perusahaan dengan modal sendiri. DER juga dapat berarti sebagai kemampuan perusahaan dalam memenuhi kewajiban membayar utangnya dengan jaminan modal sendiri. 
Eka Ajeng Dian Anggraini: Determinan Return Saham

$$
\text { Debt to equity ratio }=\frac{\text { Total Utang }}{\text { Total Ekwitas }} \times 100 \%
$$

\section{Risiko Sistematis (X2)}

Menurut Tandelilin (2010: 102) risiko sistematis adalah risiko yang berhubungan dengan fluktuasi seluruh pasar. Fluktuasi tersebut bisa berpengaruh terhadap return investasi. Perhitungan yang biasa digunakan untuk menghitung risiko sistematis adalah beta, karena beta adalah koefisien yang linear return pasar terhadap return perusahaan pada permodelan CAPM.

Menurut Agus (2001) penghitungan beta saham adalah sebagai berikut:

$$
\beta=\frac{n \Sigma \mathrm{RmRi}-\Sigma \mathrm{Rm} \Sigma \mathrm{Ri}}{n \Sigma R m^{2}-(\Sigma R m)^{2}}
$$

\section{Likuiditas (X3)}

Menurut Hani (2015: 121) likuiditas adalah kemampuan perusahaan untuk memenuhui kewajiban-kewajiban jangka pendeknya Current Ratio (CR) merupakan kemampuan perusahaan untuk membayar utang yang harus dipenuhi dengan aktiva lancar.

Menurut Irham (2012) CR dapat digambarkan dengan rumus :

$$
\text { Current ratio }=\frac{\text { Current asset }}{\text { Current liabilities }}
$$

\section{Return Saham (Y)}

Menurut Mohamad (2006) return saham merupakan keuntungan yang berbentuk persentase dari modal investasi, disimpulkan return saham merupakan hasil return yang didapat modal yang ditanamkan pada investasi.

Return saham dapat dihitung sebagai berikut (Jogiyanto, 2011):

$$
\text { Return Saham }=\frac{P_{t}-P_{t-1}}{P_{t-1}} \times 100 \%
$$

\section{METODOLOGI PENELITIAN}

Jenis penelitian ini adalah kuantitatif, penelitian berdasarkan pada filsafat positivism yang bertujuan untuk meneliti populasi maupun sampel tertentu, data dikumpulan dengan menggunakan instrument penelitian, analisis data bersifat kuantitatif/statistik, yang bertujuan 
Eka Ajeng Dian Anggraini: Determinan Return Saham

untuk menguji hipotesis yang telah ditetapkan (Sugiyono, 2011: 8). Sampel yang digunakan adalah 33 saham yaitu 16 saham JII dan 17 saham LQ45 dengan menggunakan analisis regresi linear berganda dan uji beda Independent Sample T-test.

\section{HASIL PENELITIAN}

\section{Uji Asumsi Klasik}

Tabel 1. Uji Normalitas

\begin{tabular}{l|l|l}
\hline \multicolumn{2}{c}{ Unstandardized Residual } \\
\hline & JII & LQ45 \\
\hline $\mathrm{N}$ & 48 & 51 \\
\hline Asymp. Sig. (2-tailed) & .186 & .156 \\
\hline
\end{tabular}

Berdasarkan tabel di atas, saham di JII dan LQ45 berada diatas angka 0,005, maka dapat disimpulkan bahwa uji asumsi normalitas terpenuhi.

Tabel 2. Uji Multikolinearitas

\begin{tabular}{l|l|l|l|l}
\multirow{2}{*}{ Model } & \multicolumn{2}{|c|}{ JII } & \multicolumn{2}{c}{ LQ45 } \\
\cline { 2 - 5 } & Tolerance & \multicolumn{1}{c}{ VIF } & Tolerance & VIF \\
\hline X1 & .954 & 1.048 & .897 & 1.115 \\
\hline X2 & .992 & 1.008 & .996 & 1.004 \\
\hline X3 & .958 & 1.043 & .899 & 1.112 \\
\hline
\end{tabular}

Berdasarkan tabel di atas, nilai Tolerance dan VIF dari kedua indeks mendekati angka 1 dan tidak melebihi angka 10. Hal ini menunjukkan tidak terjadi masalah multikolinearitas.

\section{Tabel 3. Uji Autokorelasi}

\begin{tabular}{|c|c|c|}
\hline \multirow{2}{*}{ Model } & \multicolumn{2}{|c|}{ Durbin-Watson } \\
\hline & JII & LQ45 \\
\hline 1 & 2.410 & 1.969 \\
\hline
\end{tabular}

Berdasarkan tabel di atas, nilai Durbin-Watson pada kedua indeks mendekati dan di sekitar angka 2 yang berarti asusmsi tidak terjadinya autokorelasi terpenuhi.

Tabel 4. Uji Heteroskedastisitas

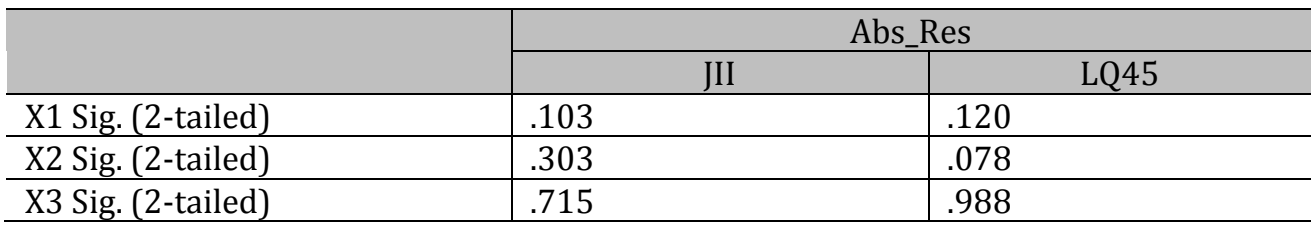

Berdasarkan tabel di atas, seluruh signifikansi X1, X2, dan X3 pada kedua indeks melebihi angka 0,05 (5\%) yang artinya tidak mengandung heteroskedastisitas atau homokedastisitas. 
Eka Ajeng Dian Anggraini: Determinan Return Saham

\section{Uji Regresi Linear Berganda}

Tabel 5. Uji F

\begin{tabular}{c|c|c|c|c}
\multirow{2}{*}{\multicolumn{2}{c|}{ Model }} & \multicolumn{2}{|c|}{ JII } & \multicolumn{2}{c}{ LQ45 } \\
\cline { 2 - 6 } & $\mathrm{F}$ & Sig. & $\mathrm{F}$ & Sig. \\
\hline 1 & 2.658 & .060 & 5.235 & .003 \\
\hline
\end{tabular}

Berdasarkan tabel di atas, pada indeks JII menyatakan bahwa $\mathrm{F}$ hitung lebih besar dari $\mathrm{F}$ tabel yaitu 2,658 > 1,69 dengan signifikansi 0,060. Jadi dapat disimpulkan bahwa secara simultan struktur modal (X1), risiko sistematis (X2) dan likuiditas (X3) memiliki pengaruh signifikan terhadap return saham. sedangkan pada indeks LQ45 menyatakan bahwa 0,003 $<0,05$ maka $\mathrm{H}_{0}$ ditolak. Jadi dapat disimpulkan bahwa secara simultan struktur modal (X1), risiko sistematis (X2) dan likuiditas (X3) memiliki pengaruh terhadap return saham.

Tabel 6. Uji t

\begin{tabular}{l|l|l|l|l}
\multirow{2}{*}{ Model } & \multicolumn{2}{|c|}{ JII } & \multicolumn{2}{c}{ LQ45 } \\
\cline { 2 - 5 } & \multicolumn{2}{|c|}{$\mathrm{T}$} & \multicolumn{1}{c}{ Sig. } & \multicolumn{1}{c}{ S } \\
\hline $\mathrm{X} 1$ & .567 & .309 & .741 & .462 \\
\hline $\mathrm{X} 2$ & -2.715 & .009 & -3.923 & .000 \\
\hline $\mathrm{X} 3$ & -.475 & .637 & -.093 & .926 \\
\hline
\end{tabular}

Berdasarkan tabel di atas, pada indeks JII struktur modal (X1) dengan nilai signifikansi sebesar 0,574 > 0,05 maka $\mathrm{H}_{0}$ diterima. Sedangkan risiko sistematis (X2) dengan nilai signifikan sebesar 0,009 < 0,05 maka $\mathrm{H}_{0}$ diterima. Kemudian likuiditas (X3) dengan nilai signifikan sebesar 0,637 > 0,05 maka $\mathrm{H}_{0}$ diterima. Jadi dapat disimpulkan bahwa secara parsial struktur modal (X1) dan likuiditas (X3) tidak memiliki pengaruh signifikan terhadap return saham. Sedangkan risiko sistematis (X2) memiliki pengaruh yang signifikan terhadap return saham. sedangkan pada indeks LQ45 struktur modal (X1) dengan nilai signifikansi sebesar 0,462 >0,05 maka $\mathrm{H}_{0}$ diterima. Sedangkan risiko sistematis (X2) dengan nilai signifikansi sebesar 0,000 $<0,05$ maka $\mathrm{H}_{0}$ ditolak. Kemudian likuiditas (X3) dengan nilai signifikansi sebesar 0,926 $>0,05$ maka $\mathrm{H}_{0}$ diterima. Jadi dapat disimpulkan bahwa secara parsial struktur modal (X1) dan likuiditas (X3) tidak memiliki pengaruh terhadap return saham sedangkan risiko sistematis (X2) memiliki memiliki pengaruh terhadap return saham. 
Eka Ajeng Dian Anggraini: Determinan Return Saham

Tabel 7. Uji Determinasi

\begin{tabular}{|c|c|c|}
\hline \multirow{2}{*}{ Model } & \multicolumn{2}{|c|}{ Adjusted R Square } \\
\hline & JII & LQ45 \\
\hline 1 & .096 & .203 \\
\hline
\end{tabular}

Berdasarkan tabel di atas, Adjusted $R$ Square pada indeks JII menunjukkan nilai sebesar 0,096 atau 9,6\% artinya kemampuan seluruh variabel terhadap return saham sebesar 9,6\% dengan sisa 90,4\% dijelaskan oleh variabel lain di luar penelitian. Sedangkan $R$ Square pada indeks LQ45 menunjukkan nilai sebesar 0.250 atau $25 \%$ artinya seluruh variabel terhadap return saham sebesar 25\%, dengan sisa $75 \%$ dijelaskan oleh variabel lain.

\section{Uji Beda JII dan LQ45}

Tabel 8. Hasil Uji Beda

\begin{tabular}{c|c|c}
\hline & F & Sig. \\
\hline $\mathrm{X} 1$ & 59.662 & .000 \\
\hline $\mathrm{X} 2$ & 1.414 & .237 \\
\hline $\mathrm{X} 3$ & .322 & .572 \\
\hline $\mathrm{Y}$ & .348 & .557 \\
\hline
\end{tabular}

Berdasarkan tabel di atas, hasil uji beda pada varibael X1 menyatakan bahwa nilai signifikansi sbesar 0,000 $<0,025$ maka dapat disimpulkan terdapat perbedaan yang signifikan antara X1 pada JII dan LQ45. Sedangkan pada variabel X2, X3, dan Y menyatakan bahwa tidak terdapat perbedaan yang signifikan antara variabel X2, X3 dan Y pada JII dan LQ45, karena nilai signifikansi > 0,025.

\section{PEMBAHASAN}

\section{Pengaruh Struktur Modal Terhadap Return Saham}

Struktur modal tidak memiliki pengaruh yang signifikan terhadap return saham di JII dan LQ45. Ini dikarenakan nilai DER tinggi timbul karena perusahaan cenderung melakukan pendanaan dengan menggunakan utang yang akan berdampak pada minat investor dalam menanamkan dananya. Investor tidak akan melihat perusahaan yang memiliki beban kredit yang tinggi sehingga harga saham tidak dipengaruhi oleh nilai DER.

\section{Pengaruh Risiko Sistematis Terhadap Return Saham}

Risiko sistematis memiliki pengaruh yang sangat signifikan terhadap return saham di JII dan LQ45. Hal ini mendukung teori adanya 
Eka Ajeng Dian Anggraini: Determinan Return Saham

high risk high return dan investor yang cenderung melakukan restrukturisasi utang, dimana investor lebih hati-hati dalam menanamkan investasinya kedalam proyek-proyek investasi yang menguntungkan karena dengan meminimalkan risiko akan meraih keutungan yang optimal.

\section{Pengaruh Likuiditas Terhadap Return Saham}

Likuiditas tidak memiliki pengaruh terhadap return saham di JII maupun di LQ45. Hasil dalam penelitian ini tidak mendukung teori bahwa likuiditas yang tinggi sejalan dengan return perusahaan yang tinggi. Nilai untuk CR hanya $1: 1$ atau diatas 1 . Sedangkan dari hasil olahan data menunjukkan bahwa rata-rata nilai CR berada diatas 2 . Menurut Weaver \& Weston dalam Fahmi (2012) pada penelitian Aufa (2013) bahwa setiap nilai yang terlalu tinggi dapat mengindikasikan adanya masalah. Jika utang lancar bertambah tinggi tetapi tidak diimbangi dengan naiknya aktiva lancar, maka bisa dikatakan "tidak likuid". Menurut penelitian Pamungkas \& Haryanto (2016) walaupun aktiva perusahaan kecil perusahaan dapat meningkatkan return. artinya likuiditas yang rendah tidak akan menjamin return yang rendah juga.

\section{Uji Beda JII dan LQ45}

Pada variabel X1 menunjukkan perbedaan yang signifikan antara JII dan LQ45. Hal ini dikarenakan saham yang ada LQ45 beberapa ada yang berasal dari bank, nilai DER dari bank sangat tinggi. Hal itu yang membuat struktur modal memiliki perbedaan yang signifikan. Sedangkan pada variabel X2, X3 dan Y menunjukkan tidak terdapat perbedaan yang signifikan pada indeks JII dan LQ45.

\section{KESIMPULAN}

Sesuai dengan hasil analisis data dan pembahasan yang dilakukan, maka dapat ditarik kesimpulan bahwa secara parsial variabel risiko sistematis pada indeks JII dan LQ45 memiliki pengaruh yang signifikan terhadap return saham. Sedangkan variabel struktur modal dan likuiditas tidak memiliki pengaruh yang signifikan terhadap return saham pada indeks JII dan LQ45. Pada uji beda, variabel struktur modal menunjukkan perbedaan yang sangat signifikan antara di JII dan LQ45. Sedangkan variabel risiko sistematis, likuiditas, dan return saham 
Eka Ajeng Dian Anggraini: Determinan Return Saham

menunjukkan tidak terdapat perbedaan yang signifikan antara di JII dan LQ45.

\section{SARAN}

Bagi investor sebelum menginvestasikan sahamnya pada suatu perusahaan investor harus selektif dalam memilih emiten atau indeks yang menguntungkan dan mengetahui apakah terdapat perbedaan yang signifikan pada kedua indeks tersebut yaitu JII dan LQ45. Untuk peneliti selanjutnya diharapkan bisa memperbanyak obyek dengan tidak hanya terbatas pada indeks JII dan LQ45 saja tetapi juga pada indeks lainnya atau dapat dikerucutkan lagi pada setiap sektor pada indeks tersebut. Serta diharapkan bisa memperpanjang periode penelitian dengan menambah variabel yang hanya terbatas pada CR dan DER saja namun juga pada kinerja keuangan lainnya seperti CA, DAR dan lain sebagainya.

\section{DAFTAR PUSTAKA}

Aufa, Rahmatul. 2013. Pengaruh Struktur Modal, Risiko Sistematis, dan Tingkat Likuiditas terhadap Return Saham pada Perusahaan Finance yang Listing di Bursa Efek Indonesia, Skripsi. Fakultas Ekonomi Universitas Negeri Padang.

Hani, Syafrida. 2014. Teknik Analisa Laporan Keuangan. Medan: In Media. Fahmi, Irham. 2012. Analisis Laporan Keuangan. Cetakan Ke-2. Bandung: Alfabeta.

Sutrisno. 2003. Manajemen Keuangan Teori, Konsep, dan Aplikasi . Yogyakarta : Ekonosia

Tandelilin, Eduardus. 2010. Portofolio dan Investasi .Yogyakarta: Kanisius.

Sartono, Agus. 2001. Manajemen Keuangan Teori dan Aplikasi. Yogyakarta: BPEF-YOGYAKARTA.

Samsul, Mohamad. 2006. Pasar Modal \& Manajemen Portofolio. Surabaya: Erlangga.

Sugiyono. 2011. Metode Penelitian Bisnis (Pendekatan Kuantitatif, Kualitatif, dan $R \& D$ ). Bandung: Alfabeta.

Jogiyanto, H. (2011). Metodologi Penelitian Bisnis. Edisi Keempat. Yogyakarta: BPFE. 